\title{
Krop og civilisering: Om unge danske pigers forhold til den nøgne krop i forbindelse med omklædning
}

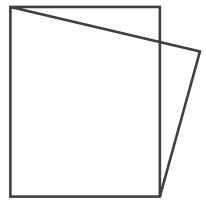

Maria Gliemann

Hybholt, ph.d.-

studerende og

Lone Friis Thing,

lektor, Institut for

Idræt og Ernæring,

Københavns

Universitet
Artiklen belyser, hvordan unge pigers forhold til bade- og omklædningssituationen involverer en ubehagelig skamfølelse. Over halvdelen af de normalvægtige unge piger vurderer, at deres vægt er lidt eller alt for høj, mens hele $57,9 \%$ af de undervægtige piger synes deres vægt er tilpas (Sundhedsstyrelsen, 2011). Rasmussen \& Due (2011) finder ligeledes, at næsten hver anden pige i 9. klasse i Danmark føler sig for tyk, mens ca. hver tredje er på slankekur, selvom $83,2 \%$ af pigerne er normal- eller undervægtige (Ekholm et al., 2006). Det kan således tyde på, at der er en skævvridning mellem den fysisk sunde krop og idealkroppen, som påvirker de unge danske pigers kropsopfattelse. I forlængelse heraf viser Nielsen et al. (2011a), at $18 \%$ af de 1. årsstuderende og $10 \%$ af de 3 . årsstuderende i gymnasieskolen ville foretrække ikke at skulle vise sig nøgen eller skulle bade efter idræt (Nielsen et al., 2011a). I en norsk kvantitativ undersøgelse viser Wabakken (2010) samme tendens. Her meddeler $35,8 \%$ af de 2. årsstuderende, at de sjældent eller aldrig bader i omklædningsrummet efter idræt, og $33,7 \%$ af dem er svært ukomfortable med at bade nøgne (Wabakken, 2010). Wabakken viser, at $43,9 \%$ af de adspurgte norske piger har droppet at deltage $i$ idrætstimen en eller flere gange pga. manglende lyst til at bade. Endvidere viser en ældre undersogelse (Flagestad, 1996), at 23,5\% af pigerne i 9. klasse heller ikke bryder sig om at klæde om og bade med deres klassekammerater. Badeproblematikken synes således at være mindst lige så udbredt i Norge som i Danmark. I forlængelse heraf kan artiklens kvalitative bidrag virke yderst relevant for at forstå, hvordan bade- og omklædningssituationens skamfulde aspekt kan påvirke pigernes idrætsdeltagelse, og herigennem indirekte influere på deres generelle trivsel og sundhed. 


\section{Formålet med artiklen er at belyse, hvordan forholdet mellem samfund og krop kan påvirke de unge pigers handlinger i bade- og omklædningssituationen efter idræt.}

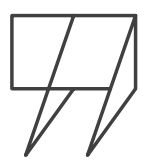

Formålet med artiklen er at belyse, hvordan forholdet mellem samfund og krop kan påvirke de unge pigers handlinger i bade- og omklædningssituationen efter idræt. Undersøgelsen er teoretisk inspireret af Norbert Elias (2000; 2008) samt Erving Goffman (1982; 1990) primært med fokus på teoretikernes sociale forståelse af følelsen skam og dens indflydelse på individets handlinger.

\section{Baggrund: Civiliserende kropsidealer} I den senmoderne vestlige verden har kropsidealer i en længere periode været præget af et ydre fokus, der symboliserer sundhed, ungdom, fitness og skønhed (Turner, 1992; Frank, 1991). Gennem medier som f.eks. reklamer, teenagefilm og musikvideoer overvældes de unge af idealiserede kroppe, som ofte er rettet til perfektion gennem computerteknologi (Nielsen et al., 2011b). Kroppens ydre er særdeles central $i$ individets præsentation af sig selv og repræsenterer herigennem et symbol på social værdi - jo større overensstemmelse med de eksisterende kropsidealer, jo højere værdi (Frank, 1991). I forlængelse heraf tillægger $84,7 \%$ af de danske unge udseendet "nogen", "stor" eller "meget stor" betydning (Nielsen et al., 2011b) samtidig med, at de føler et ansvar for selv at udforme deres krop. Kroppen kan således føles som et projekt, der konstant kræver arbejde for at præsentere sig selv og sit udseende bedst muligt (Damkjær, 1997; Smith Maguire, 2008). Undersøgelser har vist, at piger i puberteten begynder at betragte deres krop som et objekt, og at yngre kvinder i højere grad objektiviserer deres krop end ældre kvinder (Knauss et al., 2008). I relation hertil er der de seneste årtier sket en betydelig stigning i deltagerantallet inden for de individuelle fysiske aktivitetsformer, som f.eks. styrketræning, aerobic og jogging, som blandt de 16-19-årige danskere er de mest populære aktivitetsformer (Pilgaard, 2008). Ifølge Nielsen et al. (2011b) involverer fitnesskulturen en idealisering af kroppen, hvor et fokus på fejl og mangler ofte er til stede, hvorfor den stigende interesse inden for de nævnte aktivitetsformer sandsynligvis kan anskues som et forsøg på at forme kroppen efter idealet (Maguire \& Mansfield, 1998; Smith Maguire, 2008).

\section{Metode}

Studiets kvalitative empiri bygger på fokusgruppeinterviews, individuelle interviews og feltarbejde på en dansk gymnasieskole i forbindelse med et kandidatspeciale (Hybholt, 2012).

Fokusgruppeinterviews kan anskues som aktuelle i forsøget på at belyse gymnasiepigers normer i bade- og omklædningssituationen for at kunne forstå deres handlemønstre (Nielsen \& Thing, 2013). Der anvendes fem forskellige vignetter i fokusgruppeinterviewene for at få pigerne til at forholde sig til og diskutere deres egne erfaringer med bade- og omklædningssituationen (Hybholt, 2012). Der er taget højde for vignetternes rele- 
Tema: Kultur og civilisering

vans, familiaritet og generaliserbarhed (Heldbjerg, 2009) blandt andet gennem kritisk gennemlæsning af to kvindelige gymnasielærere. For at overkomme eventuelle begrænsninger ved fokusgruppeinterviews er der endvidere foretaget individuelle semistrukturerede interviews. Der er derudover foretaget observation af omklædningsrummene uden pigernes tilstedeværelse og feltarbejde i forbindelse med idræt generelt. Grundet etiske overvejelser (Kvale \& Brinkmann, 2009) vedrørende omklædningssituationens følsomme aspekt er observation af selve omklædningssituationen fravalgt, trods relevans i forhold til direkte at aflæse deltagernes interaktion med det sociale miljø (Ytting, 2013; Raudaskoski, 2010). Observationerne fungerer derfor som et forståelsesmæssigt baggrundstæppe for tolkningen af interviewene. Kombinationen af metoderne anskues som komplementerende hinanden, da produktionen af samfundsorienteret viden om fænomener eller fortolkninger ofte involverer en multipel kompleksitet (Halkier, 2009).

Indsamlingen af empirisk materiale blev foretaget i efteråret 2011 og består af to fokusgruppeinterviews og to individuelle interviews, der resulterede i 6.5 timers interviewdata optaget på diktafon svarende til cirka 220 siders transskriptionsmateriale. Hver fokusgruppe bestod af tre piger, der kendte hinanden. En af pigerne deltog både $\mathrm{i}$ fokusgruppe og efterfølgende i et individuelt interview.

Således var der i alt syv piger, der deltog i interviewene. Pigerne var mellem 18 og 19 år og var alle studerende på tredje år.

Studiets analysestrategi har været at høre og læse datamaterialet fra ét interview igennem flere gange for at danne et helhedsperspektiv (Kvale \&
Brinkmann, 2009). Herefter er foretaget en meningskodning og efterfølgende en meningsfortolkning. Samme procedure er foretaget med alle interviews. Studiet anvender en abduktiv begrundelsesform, da der forekommer en relativ gensidig indflydelse mellem empirisk teori og teoretisk empiri (Birkler, 2007).

\section{Teori: Samfundsmæssig civilisering} Elias' civilisationsteori implicerer en historisk præsentation af en øget selvkontrol hos individet gennem en eskaleret anvendelse af en tabubelagt skamfølelse, mens Goffman fremstiller individet som værende konstant på vagt for at præsentere sig selv på den bedst mulige måde for at undgå skam (Scheff, 2000; Scheff, 2003).

Væsentligt for Elias' beskrivelse af udviklingen af det moderne differentierede samfund er, at der gennem en internalisering af de sociale forbud mod fysisk vold etableres et "super-ego" i form af ubevidste dybdestrukturer, som medvirker en øget selvkontrol (Thing, 2010). Ifølge Elias (2000) er rationalisering og en lavere skamtærskel begge aspekter af civilisationsprocessens transformation af den sociale personlighedsstruktur, og de kan således forstås som to forskellige funktioner af individets automatiske selvkontrol. En overvægt til den førstnævnte medfører rationaliseret adfærd, hvorfor forudsigelige handlinger bliver en væsentlig del af sociale relationer i det civiliserede samfund. Emotionelle udbrud signalerer, at individet kan fremstå uberegnelig. Kontrollen og reguleringen af følelser bliver yderst afgørende i individets forsøg på at opnå og vedligeholde sin position i de civiliserede sociale netværk (Van Krieken, 2002).
Gennem både en ubevidst og en bevidst selvkontrol behersker det moderne menneske, ifølge Elias (2000), sig selv og sine følelser ved at undertrykke dem i den offentlige sfære og henlægge dem til privatsfæren (Elias \& Dunning, 2008; Thing 2000; Thing, 2010). Undertrykkelsen kan skabe en selvforstærkende spiral, hvor undgåelse medvirker undgåelse, fordi individet skammer sig over skamfølelsen (Scheff, 2009). Elias' civilisationsteori implicerer således en forestilling om øget kontrol af selvet gennem en eskaleret anvendelse af skam og samtidig en stigende undertrykkelse heraf gennem en videregivelse af en tabubelagt skamfølelse.

Civilisationsprocessen mindsker således tærsklen for følelsen af skam, uden vi er bevidste herom. Tabuiseringen af skam kan på den måde relatere til handlinger, der er signifikante for den sociale kontrol i samfundet (Scheff, 2003).

\section{Ritualer og skam i det sociale møde} Hvor Elias analyserer de historisk betingede samfundsmæssige og overordnede tendenser, belyser Goffman hverdagslivet som en virkelighed, der bliver iscenesat gennem mellemmenneskelige mikroritualer (Hviid Jacobsen $\&$ Kristiansen, 2002). Ritualerne har en strukturerende og begrænsende indflydelse på individets handlingsmuligheder (Goffman, 1982), hvorfor de kan betragtes som en form for samfundsmæssige normative adfærdsregler i hverdagslivet. Goffmans regler og ritualer kan anskues som relationelt afhængige i tråd med Elias' figurationelle forståelse.

I henhold til en samfundsmæssig normativ vurdering anskuer Goffman (1982) "ansigtet" som en positiv social værdi, 


\section{Studiets kvalitative empiri bygger på fokusgruppeinterviews, individuelle interviews og feltarbejde på en dansk gymnasieskole i forbindelse med et kandidatspeciale.}

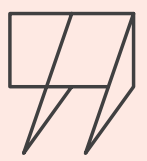

individet gør krav på, og som accepteres af de øvrige tilstedeværende. Individet oplever en emotionel tilknytning til sit ansigt og reagerer derfor følelsesmæssigt på, hvordan det behandles i det sociale møde. Det sociale møde handler ifølge Goffman om at undgå begivenheder, der kan "true ansigtet", f.eks. ved at beherske sig selv, og dermed undgå skam og den forlegenhed, der kan opstå over den følte skam (Goffman, 1982). Skam handler om uopfyldte forventninger til individet, og er potentielt til stede i alle sociale møder (Goffman, 1956). Men det er ikke kun individet, som kan føle situationens skam, de tilstedeværende vil ofte føle sig forlegne på vegne af individet. Skam kan ifølge Scheff (2000) forstås som den mest sociale af de grundlæggende emotioner og bliver essentiel for social kontrol gennem individernes konstante forventning til den.

De handlinger, individet udøver for at opretholde ansigt og undgå den potentielle skam, formidles som rutinemæssig praksis i henhold til det omgivende samfunds ritualer (Goffman, 1982: 13), hvilket kan virke samstemmende med Elias' forståelse af en automatiseret selvkontrol (Elias \& Dunning, 2008; Thing, 2010). Opsummerende kan skam både hos Goffman og Elias forstås som en almindelig og nødvendig social følelse, der er med til at påvirke individets handlinger i det sociale møde og herigennem få individet til at fremstå socialt kompetent. For at forstå pigernes handlemønstre i bade- og omklædningssituationen efter idræt i gymnasieskolen vil vi i analysen anvende Goffmans fokus på hverdagens samspil til at belyse den konkrete bade- og omklædningssituation efter idræt i gymnasieskolen, mens Elias hovedsageligt anvendes til at forstå situationens kulturelle og historiske skam.

Analyse: Civiliserende adfærdsregler i bade- og omklædningssituationen I sociale møder figurerer der nogle samfundsmæssige civiliseringsnormer, som udtrykkes gennem ritualistiske regler for passende adfærd, hvilke strukturerer individers handlinger (Goffman, 1982). En betydningsfuld norm i artiklens perspektiv vedrører et ønskeligt kropsideal. Pigerne udtrykker generelt et fælles ideal, der involverer en slank krop med pæne bryster.

"Flotte bryster og sådan helt tynd og ikke nogen strœkmcrker eller appelsinhud, som jeg også er godt udstyret med efterhånden. Og en røv når man spœndte den, så blev ens hud ikke grim. Hvis man så sådan ud, så ville jeg jo ikke have noget problem med at gå nøgen rundt" (Line).

En kollektiv forståelse af, at det er den slanke kropsform, der er ønskværdig blandt pigerne, kan kræve en relativ gennemgående selvkontrol for herigennem at sikre sig en vis position i fællesskabet. Citatet viser, at Line i høj grad er bevidst om, hvordan idealkroppen fremtræder, og at hendes egen krop ikke fremstår overensstemmende hermed. I forlængelse heraf udtrykker Line, at hun har begrænsede handlemuligheder $\mathrm{i}$ 


\section{Gennem både en ubevidst og en bevidst selvkontrol behersker det moderne menneske, ifølge Elias (2000), sig selv og sine følelser ved at undertrykke dem i den offentlige sfære og henlægge dem til privatsfæren.}

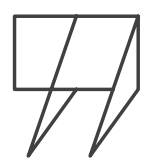

bade- og omklædningssituationen med sin nuværende krop i forhold til, hvis hun havde haft en idealkrop. Pigerne forpligtes således normativt til at handle i overensstemmelse med idealet for at figurere som kompetente agenter. Nedenstående afsnit vil uddybende belyse, hvorledes det samfundsmæssige kropsideal indirekte påvirker pigerne i bade- og omklædningssituationen gennem deres emotionelle tilknytning til deres ansigt og forsøget på at opretholde det.

\section{Ansigt og selvopretholdelse i badning} Enhver situation fordrer, at pigerne hver især gør krav på et specifikt socialt ansigt, som de andre deltagere i situationen skal være villige til at anerkende som passende for personen, hvilket kræver en overensstemmelse med samfundets normer (Goffman, 1982).

"De kan ikke lade vœre med at kigge på sig selv, og så kigge på mig, og så tœnke, at de da bare er meget meget pœnere end mig" (Sara).

Som citatet antyder, tillægger Sara sin egen rolle i bade- og omklædningssituationen et mindre betydningsfuldt socialt ansigt i forhold til de andre piger. Ikke desto mindre oplever hun, som de andre, en emotionel tilknytning til det. Den emotionelle tilknytning tydeliggøres bl.a. gennem pigernes beretninger om at føle sig udstillede, sårbare og bange for, hvad de andre tilstedeværende vil tænke om dem.

"Jeg tror, det er mest sådan, at man er bange for, at andre tœnker noget dårligt om en" (Line).

Pigernes emotionelle tilknytning til ansigtet kan således forstås yderst social, da den medvirker til en følelsesmæssig reaktion afhængig af, hvordan de andre behandler ansigtet i situationen. I forlængelse heraf kan positive tilbage- meldinger fra de andre give pigerne en følelse af at have det bedre med at vise sig frem. Omvendt beretter nedenstående citat om det konstante følelsesmæssige negative aspekt, Sara oplever i forbindelse med bade- og omklædningssituationen.

"Der er ikke nogle gange, hvor jeg bare er ligeglad, så kan det godt vœre, at jeg prøver at tage mig sammen eller prøver at virke ligeglad eller sige til mig selv, at nu må du bare gøre det, men jeg tœnker da over det, altså det er da noget jeg virkelig ikke bryder mig om" (Sara).

Ifølge citatet forsøger Sara at skjule sine følelser, til trods for deres umiddelbare store indflydelse på hendes velbefindende. Den emotionelle tilknytning til ansigtet medfører, som tidligere nævnt, et engagement $\mathrm{i}$ at opretholde sit eget og de andres ansigt i situationen, hvorfor Sara f.eks. forsøger at skjule sine følelser gennem en væsentlig selvkontrol. 
Krop og civilisering

Ifølge Goffman (1982) forsøger ethvert individ at handle, således at der opstår en vis overensstemmelse mellem ansigt og rolle. På den måde kan individet undgå potentielle trusler mod ansigtet. I bade- og omklædningssituationen kan det "at gemme sig" bag en anden, at holde håndklædet om sig og ikke at snakke, mens man er afklædt være eksempler på, hvordan pigerne sammen forsøger at opretholde ansigt. Handlingerne, individet udfører for at opretholde ansigt i situationen, kan være ubevidste såvel som bevidste, men er i forlængelse af det teoretiske perspektiv påvirket af samfundets normer. Nedenstående eksempel viser, hvordan pigerne kan være opmærksomme på at fremstille dem selv på den bedst tænkelige måde i relation til samfundets kropsideal.

"Jeg er meget bevidst om mig selv, når jeg går, så jeg går måske på sådan en underlig måde, det føler jeg i hvert fald jeg gør, jeg prøver at dœkke så meget som muligt og vende i gode vinkler, men hvis jeg vender for meget af siden til, så kan man også se dellen og sådan noget, altså helst bagfra eller fra venstre side, det er den bedste vinkel" (Line).

Citatet viser, at Line tænker meget over, hvordan hun præsenterer sig selv i badeog omklædningssituationen. Hun går på en helt bestemt måde for at undgå trusler i form af eventuel unødvendig opmærksomhed fra de andre tilstedeværende og dermed kunne opretholde sit ansigt i situationen. Ligeledes vender hun ryggen til i badet for at kunne ignorere de andres direkte blikke, der kan virke truende mod ansigtet. På den måde opretholder hun sit ansigt ved at handle $\mathrm{i}$ overensstemmelse med de pågældende adfærdsregler.
Nogle gange kan bade- og omklædningssituationen kræve så stor en indsats for at opretholde ansigt, at nogle piger hellere vil undgå situationen.

"Jeg havde virkelig virkelig, virkelig ikke lyst til at have idrœt, det var nœrmest en kamp hver gang for ikke bare at gå hjem, der var også nogle morgener, hvor at jeg havde pakket idrœtstøj og kom, men simpelthen valgte ikke at gå til idrœt, men gik over i hovedbygningen på skolen i stedet for, for jeg kunne bare ikke overskue det" (Sara).

Selvom Sara har været fuldstændig fysisk klar til at klæde om, har hun nogle gange valgt at undgå idræt. Det kan formodentlig forstås ved hjælp af den mulige trussel af ansigtet, som bade- og omklædningssituationen indebærer for hende. Undgåelse af situationen kan skyldes, at hun føler, at truslen er tilstrækkelig stor til at kunne skabe uoverensstemmelse mellem hendes ansigt og de andres opfattelse af hende som person. Det kan således tyde på, at frygten for at tabe ansigt og følelsen af skam kan få hende til at undvige badeog omklædningssituationen.

Bade- og omklædningssituationen involverer ud fra ovenstående en høj grad af ansigtsarbejde blandt pigerne for at kunne opretholde deres selvopfattelse og de andres opfattelse af dem. I forlængelse heraf skabes samtidig mangfoldige muligheder for at mislykkes i forsøget på at efterleve adfærdsreglerne og de andres forventninger, hvormed følelsen af skam kan opstå. Nedenstående afsnit vil belyse den sociale skam i bade- og omklædningssituationen og med udgangspunkt i teorien koble skam til en fremtrædende selvkontrol.

\section{Skam og den civiliserende selvkontrollerede krop}

Som tidligere nævnt betragtes samfundets slanke kropsideal som normen for de interviewede piger. I og med bade- og omklædningssituationen involverer en præsentation af en nøgne krop, kan det medføre en relativ stor risiko for at føle skam, da det langt fra er alle pigerne, der føler, at de kan efterleve kropsidealet. Nedenstående citat vidner om, hvorledes Sara objektiverer sin krop ved at italesætte den i negative vendinger.

"Den (sin krop) er ulœkker ... jeg tœnker jo bare dårligt om den ... det er vist bare alt jeg tœnker 'adr' med den" (Sara).

Ovenstående citater kan indikere, at Sara i høj grad er bevidst om idealets kropsform og tillige, at hendes krop ikke kan leve op til kravene. Sara føler umiddelbart en fundamental personlig skam over sin krop, hvilken sandsynligvis opstår, fordi hun frygter de andres overlegenhed og dermed muligheden for social degradering. På samme måde kan pigernes fokus på egne utilfredsstillende kropsdele og andres ideelle kropsdele være et udtryk for frygten for ikke at kunne forhindre de andres overlegenhed og dermed følelsen af skam.

Ifølge Elias (2000) stiger kravet om individets selvkontrol i sammenhæng med en lavere tærskel for følelsen af skam i civiliserede samfund. Den relativt lave tærskel kommer blandt andet til udtryk ved, at skam opleves ved mindre og mindre uoverensstemmelser mellem personens påkrævede ansigt og de andres opfattelse af personen. F.eks. har Line et behov for at vide, hvordan hun bør se ud helt ned til mindste detalje omkring intimbehåring, og tillige hvilken metode hun skal anvende for at fjerne den. 
Tema: Kultur og civilisering

"Man ved heller aldrig rigtig, om man skal shavet eller hvordan det (intimbehåring) skal se ud, hvordan sådan alt skal se ud, så det er sådan, altså jeg føler mig bare blottet" (Line).

Den umiddelbare lave tærskel for skam i bade- og omklædningssituationen kan således virke til at påvirke de deltagende piger i høj grad, da de tænker over, hvordan hver enkelt kropslig deltalje bør se ud. De føler, at de skal have kontrol over det hele for at kunne undgå den nærtliggende skam. I forlængelse heraf kan pigernes udsagn vedrørende kønsdelene, som kroppens mest intime og private dele, være udtryk for, at blottelse af netop disse kropsdele kan være risikabelt i forhold til følelsen af skam.

"Men det er bare som om trusserne, de dœkker et eller andet sådan ... altså der er bare så mange ting, der sker dernede $i k$ '. Man har menstruation, man tisser, man har sex, man skider, man prutter, og man altså der er bare så mange sådan ... huller (fniser)" (Line).

Som Line fnisende kommenterer, så dækker trusserne de dele af kroppen, som pigerne ikke selv har mulighed for at kontrollere. Man kan ikke selv styre, hvornår man har menstruation, man skal tisse osv., hvilket kan medføre en form for afmagt hos pigerne. Man kunne forestille sig, at behovet for at skjule de intime kropsdele med trusser hurtigst muligt kan skyldes den manglende mulighed for kontrol. Samtidig kan afmagten medvirke, at pigerne føler, at det er de mest intime og private dele af kroppen, da de har et behov for, at disse dele kun er præsenteret på bagscenen, hvor de ikke behøver at opretholde et bestemt ansigt.
Følgende citat kan give et indtryk af, hvordan den ovennævnte selvkontrol i bade- og omklædningssituationer kan involvere en undertrykkelse af følelser $i$ den offentlige sfære.

"Det er heller ikke, fordi jeg synes, det er helt vildt behageligt (at tage trusserne af), og jeg har det helt vildt godt med det, men det er sådan lidt, man lukker bare lidt øjnene for det, og så går man $i$ bad, og så er det fint nok" (Rikke).

\section{Selvom Rikke i interviewet udtrykker} en almen tilpashed ved sin nøgne krop, kan det også for hende indebære en vis utilpashed at tage trusserne af. Alligevel går hun i bad og kontrollerer dermed de ubehagelige følelser ved at undertrykke dem, hvormed de i stedet formentlig samler sig sammen inden i hende (Elias, 2000). På den måde skjuler hun skammen over at skulle tage trusserne af foran de andre og redder dermed situationen og de implicerede ansigter. Der opstår således en form for skam over skamfølelsen, hvormed skam kan anskues som tabubelagt i bade- og omklædningssituationen.

Tabuiseringen af skam kan, gennem en høj grad af skam og en lav bevidsthed herom, bevirke en betydelig social kontrol. F.eks. dækker pigerne deres krop mest muligt med håndklæder, Line skjuler sine tatoveringer og har det dårligt over at tage sine sko af, fordi de er svedige og lugter, og Sara gør alt for ikke at blive set af de andre.

"Jeg kunne aldrig finde på at stille mig nøgen $i$ et omklœdningsrum, aldrig, aldrig, aldrig, aldrig og heller ikke $i$ undertøj, aldrig nogensinde, det ville jeg godt nok ikke gøre!" (Sara).
Citatet og ovennævnte eksempler kan bevidne om en forventning til, hvilke handlinger der kan bevirke skamfølelsen. Pigerne handler således i forsøget på at undgå situationer, der kan bibringe følelsen af skam for ikke at risikere at tabe ansigt. På den måde skabes en normativ social orden i bade- og omklædningssituationen gennem forventningerne til følelsen af skam ved præsentationen af den nøgne krop foran de andre i ens figuration. Ovenstående analyse kan således tyde på, at bade- og omklædningssituationen implicerer en høj grad af undertrykt skam og udøvet selvkontrol i relation til en væsentlig normativ social kontrol gennem det slanke kropsideal.

\section{Konkluderende afslutning}

Artiklen viser, hvordan samfundets civiliserende normer kommer til udtryk gennem bade- og omklædningssituationens adfærdsregler. Pigernes fælles idealiserede kropsforståelse forpligter dem til at handle i overensstemmelse hermed for at fremstå som kompetente agenter. Jo højere grad af overensstemmelse, jo bedre muligheder for at positionere sig selv fordelagtigt i figurationen. Kroppens præsentation er et afgørende element for pigernes position i figurationen (Maguire \& Mansfield, 1998; Mansfield, 2010), og da bade- og omklædningssituationen involverer en direkte social præsentation af pigernes nøgne krop, kan kropslige uoverensstemmelser med idealet virke nødvendige, men yderst vanskelige at skjule. Bade- og omklædningssituationens sociale præsentation af den nøgne krop implicerer således en relativ stor risiko for følelsen af skam.

Pigernes udsagn viser, hvordan de gennem en emotionel tilknytning til "det sociale ansigt" forsøger, bevidst 


\section{Pigerne forpligtes således normativt til at handle i overensstemmelse med idealet for at figurere som kompetente agenter.}

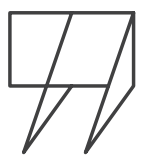

som ubevidst, at udøve en høj grad af selvkontrolleret ansigtsarbejde for at opretholde deres selvopfattelse og de andres godkendelse heraf for at undgå en skamfuld situation. Pigerne tænker over selv den mindste detalje, som f.eks. metode til intimhårfjerning og strækmærker, og de udtrykker et betragteligt krav om at have en passende kropslig selvkontrol for at forhindre den potentielle skam. Skam fungerer således som en slags indikator for, hvornår pigernes ansigt trues. For nogle piger kan badeog omklædningssituationen involvere en tilstrækkelig stor risiko for at føle skam til, at de enten dropper badet eller pjækker fra idræt i gymnasieskolen. Frygten for skam kan således medføre isolerende handlinger i relation til idræt i gymnasieskolen, hvorfor at pjække fra idræt kan anskues som en utilsigtet konsekvens af den sociale skamspiral.
Artiklen viser, at nutidens danske samfund implicerer et slankt kvindeligt kropsideal for de unge piger. Pigerne føler, at de ikke lever op til kropsidealet, og der fremtræder generelt en relativ lav tærskel for følelsen af skam i bade- og omklædningssituationen, hvilket påvirker pigernes handlinger i betydeligt omfang. Kroppens sociale skam kan således virke til at være en relevant problematik for unge piger i de vestlige kulturer (Flagestad, 1996; Rasmussen \& Due, 2011; Skårderup, 2006; Strauss, 1999). Vi har brug for mere empirisk forskning, der går i dybden med de sociale forandringsprocesser i forholdet til kroppen - også de hverdagslige mikroorienterede interaktioner i idræt (Mierzwinski et al., 2014; Thing \& Ottesen, 2013). 
Tema: Kultur og civilisering

\section{REFERENCER}

Birkler, Jacob (2007). Videnskabsteori - en grundbog (pp. 66-82). København: Munksgaard Danmark.

Collins, Randall (1994). Four Sociological Traditions. New York: Oxford University Press.

Creswell, John W. (2007). Qualitative Inquiry \& Research Design. Choosing Among Five Approaches (2nd ed.). Sage.

Damkjær, Søren (1997). Kroppens sociologi og sundhedsteorien. In H.P. Hansen \& P. Ramhøj (eds.) Tvœrvidenskabelige perspektiver på sundhed og sygdom (pp. 42-64). Akademisk Forlag A/S.

Ekholm, O., Kjøller, M., Davidsen, M., Hesse, U., Eriksen, L., Christensen, A., et al. (2006). Sundheds-og sygelighedsundersøgelsen 2005 \& udviklingen siden 1987. København: Statens Institut for Folkesundhed.

Elias, Norbert (2000 [1994]). The Civilizing Process. Sociogenetic and Psychogenetic Investigations (Revised edition). Oxford: Blackwell.

Elias, N. \& Dunning, E. (2008). Quest for Excitement. Sport and Leisure in the Civilising Process (pp. 44-106). Oxford: Basil Blackwell.

Flagestad, L. (1996). Trivsel i kroppsøvingsfaget. En undersøkelse av trivselen i kroppsøvingsfaget blant 7. og 9. klassinger i Kristiansand kommune. Hovedfagsopgave: Norges idrettshøgskole, Oslo.

Frank, Arthur W. (1991). For a Sociology of the Body: An Analytical Review. In M. Featherstone, M. Hepworth \& B.S. Turner (eds.) The Body: Social Process and Cultural Theory. SAGE.

Goffman, Erving (1956). Embarrassment and social organization. The American Journal of Sociology, 62(3), 264-271.

Goffman, Erving (1971). Relations in Public. Microstudies of the Public Order (pp. 44-49). London: Allen Lane The Penguin Press.

Goffman, Erving (1982 [1967]). Interaction Ritual. Essays on face-to-face behavior. New York: Pantheon Books.

Goffman, Erving (1990 [1959]). The presentation of self in everyday life. Great Britain: Penguin Books.
Halkier, Bente (2009). Fokusgrupper (2nd ed.). Frederiksberg: Samfundslitteratur.

Heldbjerg, Grethe (2009). Kulturforståelse og forandring. Frederiksberg: Samfundslitteratur.

Hviid Jacobsen, M. \& Kristiansen, S. (2002). Erving Goffman. Sociologien om det elementcere livs sociale former. København: Hans Reitzels Forlag.

Hybholt, M. (2012). Samfundets kontrollerende skam- et kvalitativt studie af bade- og omklædningssituationen efter idræt i gymnasieskolen. (Kandidatspeciale, Institut for Idræt, Københavns Universitet).

Knauss, C., Paxton, S.J. \& Alsaker F.D. (2008). Body Dissatisfaction in Adolescent Boys and Girls: Objectified Body Consciousness, Internalization of the Media Body Ideal and Perceived Pressure from Media. Sex Roles, 59, 633-643.

Kvale, S. \& Brinkmann, S. (2009). Interview. Introduktion til et håndværk (2nd ed.). København: Hans Reitzels Forlag.

Maguire, J. \& Mansfield, L. (1998). "No-Body's Perfect": Women, Aerobics, and the Body Beautiful. Sociology of Sport Journal, 15, 109-137.

Mansfield, L. (2010). Fit, Fat and Feminine? The Stigmatization of Fat Women in Fitness Gyms. In E. Kennedy \& P. Markula (Eds.), Women and Exercise: Qualitative research on the body, health and consumerism (pp. 81-101). London: Routhledge.

Mierzwinski, M; Velija, P.; Malcolm, D. (2014). "Women's Experiences in the Mixed Martial Arts: A Quest for Excitement?". Sociology of Sport Journal. 31: 66-84.

Nielsen, S.F., Brandt-Hansen, M., Nielsen, G., Ottesen, L. \& Thing, L.F. (2011a). Unges syn på idrœt, bevœgelse og sundhed i gymnasieskolen. En kvantitativ undersøgelse af Rysensteen Gymnasium. København: Institut for Idræt.

Nielsen, J.C., Sørensen, N.U. \& Osmec, M.N. (2011b). Når det er svœrt at vœre ung i DK- unges trivsel og mistrivsel $i$ tal ( $\mathrm{pp}$. 119-170). Center for Ungdomsforskning.

Nielsen, S.F. \& Thing, L.F. (2013). Fokusgruppeinterview. In: L.F. Thing \& L. Ottesen (eds.). Metoder i idrœtsforskning (pp. 90-105). København: Munksgaard. 
Pilgaard, M. (2008). Danskernes motions- og sportsvaner 2007 nøgletal og tendenser. Idrættens Analyseinstitut.

Rasmussen, M. \& Due, P. (2011). Skolebørnsundersøgelsen 2010. HBSC. Statens institut for Folkesundhed, Syddansk Universitet.

Raudaskoski, P. (2010). Observationsmetoder (herunder videoobservation). In S. Brinkmann \& L. Tanggaard (eds.). Kvalitative metoder - en grundbog (pp. 81-96). København: Hans Reitzels Forlag.

Scheff, Thomas (2000). Shame and the Social bond: A Sociological Theory. Sociological Theory, 18(1), 84-99.

Scheff, Thomas (2003). Shame in Self and Society. Symbolic Interaction, 26(2), 239-262.

Scheff, Thomas (2009). A Social Theory and Threatment of Depression. Ethical Human Psychology and Psychiatry, 11(1), 37-49.

Skårderud, Finn (2006). Flukten til kroppen - senmoderne skamfortellinger. In: P. Gulbrandsen, P. Fugelli, G.H. Stang \& B. Wilmar (eds.). Skam i det midisinske rom (pp.45-64). Oslo: Gyldendal.

Smith Maguire, J. (2008). Leisure and the Obligation of SelfWork: An Examination of the Fitness Field. Leisure Studies, 27(1), 59-75.

Strauss, Richard (1999). Self-reported Weight Status and Dieting in a Cross-sectional Sample of Young Adolescents. Archives of Pediatrics \& Adolescent Medicine, 153(7), 741-747.

Sundhedsstyrelsen (2011). National sundhedsprofil unge. København: Sundhedsstyrelsen.

Thing, L.F. (2000). Er emotioner som vilde galoperende heste? En mikrosociologisk anvendelse af Norbert Elias' emotionsbegreb med elitesport som eksempel. Dansk Sociologi, 1(11), 23-39.

Thing, L. F. (2010). Norbert Elias. In P. Tanggaard Andersen \& H. Timm (eds.). Sundhedssociologi (pp. 120-136). København: Hans Reitzels Forlag.

Thing, L.F. \& Ottesen, L. (2013). Young people's perspectives on health, risks and physical activity in a Danish secondary school. Health, Risk \& Society, 15(5), 463-477.
Turner, Bryan S. (1992). Kroppen i samfundet. Teorier om krop og kultur. København: Hans Reitzels Forlag.

Van Krieken, Robert (2002). Norbert Elias. København: Hans Reitzels Forlag.

Wabakken, T.V. (2010). Et følelsesladet valg. Om prosesser og mekanismer bak ikke-deltakelse i kropsøving, dusj-og garderobeaktiviteter. Masteropgave: Høgskolen i Telemark.

Ytting, Linnea (2013). Videnskabsetik. In: L.F. Thing \& L. Ottesen (eds.). Metoder i idrœtsforskning (pp. 409-425). København: Munksgaard. 